\title{
Effect of Short-term Elevation Temperature and Salinity Stress on Caspian Roach, Rutilus caspicus
}

\author{
Salman Malakpour Kolbadinezhad ${ }^{1,2 *}$, Abdolmajid Hajimoradloo ${ }^{3}$, Rasul Ghorbani ${ }^{3}$, Hamidreza Joshaghani ${ }^{4}$ and Jonathan M. $^{2}$ \\ Wilson $^{2,5}$ \\ ${ }^{1}$ Coldwater Fisheries Research Center (CFRC), Iranian Fisheries Sciences Research Institute (IFSRI), Agricultural Research, Education and Extension \\ Organization, Tonekabon, Iran \\ ${ }^{2}$ Centro Interdisciplinar de Investigação Marinha e Ambiental (CIIMAR/CIMAR), Universidade do Porto, Porto, Portugal \\ ${ }^{3}$ Gorgan University of Agricultural Sciences and Natural resources, College of Fisheries and Environment, Gorgan, Iran \\ ${ }^{4}$ Laboratory Sciences Research Center, Golestan University of Medical Sciences, Gorgan, Iran \\ ${ }^{5}$ Department of Biology, Wilfrid Laurier University, Waterloo, Canada
}

${ }^{*}$ Corresponding author: Salman Malakpour Kolbadinezhad, Coldwater Fisheries Research Center (CFRC), Tonekabon, Iran; Email: salman@ciimar.up.pt

Received: January 29, 2022; Accepted: February 03, 2022; Published: February 15, 2022

\begin{abstract}
Caspian roach, Rutilus caspicus must have adaptive mechanisms to control internal homeostasis over a broad range of ambient various such as the heat shock (HS) and salinity changes. This experiment was carried out in two stages. In first stage, thirty juveniles fish ( $3.2 \pm 0.34 \mathrm{~g})$ transferred to $20 \mathrm{~L}$ circular tanks, containing three different salinity $(5,10,15 \mathrm{ppt})$. Initially, half of the treatments exposed to a HS $\left(26^{\circ} \mathrm{C}\right.$ for $\left.2 \mathrm{~h}\right)$ while the range of normal temperature was $16.5-17.5^{\circ} \mathrm{C}$. At $96 \mathrm{~h}$ after transferring, survival rate, hematocrit, plasma $\mathrm{Na}^{+}, \mathrm{K}^{+}$and $\mathrm{Cl}^{-}$and osmolality and gill NKA activity were determined. In the second stage (second $96 \mathrm{~h}$ ), all of the first treatments were transferred to $15 \mathrm{ppt}$ and similar sampling was done. In first stage, no mortality in 5 and $10 \mathrm{ppt}$ of both non heat shock (NHS) and HS treatments and higher plasma osmolality, ions (except $\mathrm{K}^{+}$), and hematocrit were observed. Mortality was observed in 15 ppt of NHS and in second stage, both treatments of 15 ppt showed mortality (15-20\%). In NHS, significant increase of gill NKA found at in $10 \mathrm{ppt}$ of second stage while in HS treatment was in $10 \mathrm{ppt}$ of first stage. Changes in plasma osmolality and electrolytes in HS treatment were more less similar to NHS treatment. Together, it seems HS and salinity changes resulted to disturbances from an internal fluid shift thus a stress situation and Caspian roach juveniles need to complete ion-osmo regulation systems for adaptation with brackish water.
\end{abstract}

Keywords: Heat shock, Salinity, Osmoregulation, Gills, Na+/K+-ATPase activity

\section{Introduction}

In teleost fishes, highly efficient ion/osmoregulatory mechanisms lead to maintenance of body fluid homeostasis, which is necessary for the normal operation of cellular biochemical/physiological processes [1]. Approximately $5 \%$ of teleost fish are euryhaline while the most teleost fish are stenohaline and cannot tolerate large changes in salinity $[2,3]$. Euryhaline teleosts have the ability to adapt to different environmental salinities while maintaining essentially constant their internal milieu by the activation of several osmoregulatory mechanisms, namely in the branchial and renal epithelia [4,5]. Gills, kidney and digestive tract are the main osmoregulatory organs in teleost fishes $[4,6]$. The rapid response and/or acute transition to changing environmental salinity become a crucial challenge for avoiding significant internal osmotic disturbances. There are two periods of acclimation for euryhaline teleosts to hyperosmotic environments: a) a crisis period (minutes to hours) involving a rapid increase in gill-ion fluxes, activating exist proteins, water transport and/or other mechanisms [7], and elevated plasma ions and osmolality followed by b) a regulatory period (hours to days onward) including increases of gill $\mathrm{Na}^{+} / \mathrm{K}^{+}$-ATPase (NKA) activity accompanied by a proliferation and development of mitochondrion-rich cells (MRCs) presumably hormonally regulated allowing for increased transport capacity [8], increasing net $\mathrm{Na}^{+}$and $\mathrm{Cl}^{-}$efflux and restoring plasma ions balance $[9,10] . \mathrm{Na}^{+} / \mathrm{K}^{+}$-ATPase, primary driving force for flux of intra and extra cellular $\mathrm{NaCl}$ which is specifically present in high concentrations on the basolateral side of MRCs, plays important roles in maintaining the cell membrane potential by pumping $\mathrm{Na}^{+}$out and $\mathrm{K}^{+}$in through active transport [9]. Changes in gill NKA activity are observed 2-3 days after transfer from a hypoosmotic to hyperosmotic environment in euryhaline teleosts [11]. In anadromous species $[12,13]$, activation of gill NKA takes place 3-7 days after transfer to SW and also in mullet and killifish, gill NKA activity elevated rapidly within $3 \mathrm{~h}$ after transfer from FW to BW or SW [14]. In both of FW and seawater (SW), the regulation of the ion levels and osmolality of body fluids of fishes are doing actively [2]. The plasma osmolalities of euryhaline teleost species of FW and SW origin vary [15] and in a number of euryhaline teleosts showed the effects of changing salinity on plasma osmolality and circulating electrolytes [16-21].

Since the most organisms on Earth are ectotherms, such as fish, surviving and adaptation to temperature fluctuations are crucial for 
them (Somero, 2010; Tang et al., 2014). Rapid water temperature changes (exceeds the optimal temperature range) or exposures to sustained temperatures outside the optimal range (thus, sub-optimal) often result in thermal stresses or lethal conditions (Portz et al., 2006). The fishes can be classified into two groups including eurythermal and stenothermal species which tolerance wide and narrow ranges of temperature, respectively [22,23]. Internal electrolyte and osmotic homeostasis in aquatic ectotherms can be influenced by environmental temperature $[17,24,25]$ which is contributed to the regulation of ion-transporting mechanisms by many proteins while stenothermal species have marginally stable of cellular proteins in a limited range of temperature $[17,24,26]$.

The Caspian roach, Rutilus caspicus (Yakovlev 1870) belongs to the Cyprinidae, the largest family among FW teleosts, is moderately euryhaline, omnivorous feeding on small crustacea and insect larvae and often lives in areas close to the estuary where water is brackish. Spring and fall migrations, from sea to the river and sea inner migration for spawning and wintering, occur in its life, respectively [27] and also considered as a significant food source for beluga sturgeon, Huso huso (L. 1758) in the Caspian Sea [10,28]. This species has been considered for inclusion in the list of threatened species for the region due to over fishing and deterioration of its spawning ground [29]. Since reproduction and sustainability of teleosts species stocks such as Caspian roach negatively are affected due to the human activities in the southern of Caspian Sea, moreover the critical importance of reconstruction such resources, fisheries organization in Iran, using artificial propagation program for releasing millions of different kinds of teleosts larva and juveniles, derived through artificial propagation, to connected rivers to the Caspian sea [10]. Being a eurythermal fish, Caspian roach like cyprinus carpio L. must have adaptive mechanisms to control internal homeostasis over a broad range of ambient temperatures particularly in releasing time (May-July) while the fish exposing to the heat shock and salinity changes in transferring processes.

The main goals of the present study were to determine the effects of short-term elevation temperature and direct salinity transferring stresses on the osmoregulatory capability of Caspian roach. Considering the value of gill NKA response it is worth to study of the impact of to environmental stresses such as temperature and salinity on osmoregulatory responses in Caspian roach. The selected salinity treatments were base of the salinity range that Caspian roach are likely to encounter in Bandare Torkaman coastal area, Gorgan bay, southeastern of the Caspian Sea, Iran.

\section{Material and Methods}

\section{Animals}

Approximately 600 juvenile (aged between 3 and 4 months) Caspian Roach, were obtained from the Sijual Teleost Fish Propagation and Rearing Center, close to the Bandare Torkaman, southeast of the Caspian Sea, Iran. The fish were transferred to Aquaculture research center of the Faculty of Fisheries and Environmental Sciences, Gorgan University of Agricultural Sciences and Natural Resources, Gorgan,
Iran. All fish were acclimatized to laboratory conditions for at least two weeks prior to experiments in six 4001 fiberglass tanks, with approximately 150 juveniles in each tank, to avoid the potentially confounding effects of handling stress (e.g. high blood cortisol) on osmoregulation [30]. Fish were fed twice daily with a commercial diet, biomar (0.8; Nersac, France) during holding. Fish were not fed during the experiment. Fish were exposed to ambient photoperiod of approximately $14 \mathrm{~h}$ light:10 h dark.

Dechlorinated tap water was used during the experiment and Caspian seawater (SW) with maximum salinity of 15 ppt (obtained from Bandare Torkaman sea shore, Gorgan Bay, Iran) were used for preparing waters of different salinities, ppt. Salinity, temperature (range $16.5-17.5^{\circ} \mathrm{C}$ ), $\mathrm{pH}$ (range 8.2-8.6) and dissolved $\mathrm{O}_{2}$ (7.6-13.3 $\mathrm{mg}^{-1}$ ) were measured daily to the nearest $0.1 \%, 0.1^{\circ} \mathrm{C}, 0.1 \mathrm{pH}$ unit, $0.1 \mathrm{mg} \mathrm{l}^{-1}$, respectively using a water quality meter (U-10, Horiba Ltd, Japan).

\section{Salinity Acclimation Experiment}

The experiment was carried out in two stages including three salinity treatments with three replicates. Feeding was stopped 24 hour before starvation. After adaptation with experimental conditions, initially, half of the treatments exposed to the heat shock (HS), $26^{\circ} \mathrm{C}$ for 2 hours (h), while the range of normal temperature was 16.5 $17.5^{\circ} \mathrm{C}$. In first stage, thirty juveniles fish $(3.20 \pm 0.34 \mathrm{~g})$ directly transferred to the $20 \mathrm{~L}$ volume plastic circular tanks, containing three different salinity (5, 10 and $15 \mathrm{ppt})$. At $96 \mathrm{~h}$ after transferring, survival rate, haematocrit, $\mathrm{Na}^{+}, \mathrm{K}^{+}, \mathrm{Cl}^{-}$and osmolality concentrations and gill NKA activity were determined.

In the second phase, all of the first phase individuals were transferred to $15 \mathrm{ppt}$. At second $96 \mathrm{~h}$ after transferring, similar sampling mentioned above were performed. Twelve individuals were sampled two times, just before transferring to other salinities (second phase). About 24 individuals, per treatment groups, of this specie were used for the experiment.

\section{Sampling}

The six fish from each treatment were anesthetized with clove powder $(100 \mathrm{mg} / \mathrm{l})$ and samples of the blood were taken immediately into a $75 \mathrm{~mm}$ heparinised capillary tubes by caudal transaction. Capillary tubes with blood samples were centrifuged at $5000 \mathrm{~g}$ (Hettich: D_78532 Tuttlingen, Germany) for $15 \mathrm{~min}$ at $4^{\circ} \mathrm{C}$, for the measurement of haematocrit (Hct) and aliquots of plasma were stored at $-80^{\circ} \mathrm{C}[10]$.

\section{Analytical Techniques}

\section{Plasma Ion and Osmolality Measurements}

Plasma $\mathrm{Na}^{+}, \mathrm{K}^{+}$and $\mathrm{Cl}^{-}$concentrations were measured using an ion-selective electrodes (Electrolit analyzer mod EI-99IE, Germany) and results reported in $\mathrm{mEq} \cdot \mathrm{l}^{-1}$. Plasma osmolality was determined in fresh samples using a freezing point depression (OSMOMETER AUTOMATIC model. Roebling, Germany) and reported as mOsmol. $1^{-1}[10]$. 


\section{Gill $\mathrm{Na}^{+} / \mathrm{K}^{+}$-ATPase Activity}

Gill NKA activity was measured according to the McCormick (1993) microassay protocol with some modifications [10,31]. Gill filament samples from the leftside second arch were served by fine point scissors, from the anesthetized fish and immersed in $100 \mu \mathrm{l}$ of ice-cold SEI buffer (150 mmol. $\mathrm{l}^{-1}$ sucrose, 10 mmol. $\mathrm{l}^{-1}$ EDTA, 50 mmol. $1^{-1}$ imidazole, $\mathrm{pH} 7.3$ ) and frozen at $-80^{\circ} \mathrm{C}$.

The thawed filaments were homogenized with pestle in SEI buffer containing $0.1 \%$ deoxycholic acid and centrifuged at $8000 \mathrm{~g}$ for $60 \mathrm{~s}$ to remove large debris. For the assay $25 \mu \mathrm{l}$ of the supernatant were added to $500 \mu$ l of assay mixture (Imidazole buffer $(50 \mathrm{mM}$ ) Phosphoenolpyruvate (2.8 mM), NADH (0.22 mM), ATP (0.7 mM), Lactic Dehydrogenase (4.0 U), Pyruvate Kinase (5.0 U). Assays were run in two sets of duplicates, one set containing the assay mixture and the other assay mixture plus ouabain $(1.0 \mathrm{mM}$; Sigma-Aldrich Chemical Co., St. Louis, MO, USA) to specifically inhibit NKA activity. ATPase activity was detected by enzymatic coupling of ATP dephosphorylation to NADH oxidation measured at $340 \mathrm{~nm}$ with a spectrophotometer (Photometer clinic $\Pi$, Iran) for $10 \mathrm{~min}$ at $30^{\circ} \mathrm{C}$. Total protein concentrations were determined by modification of the Bradford (1976) dye binding assay with a bovine serum albumin (BSA) standard at $630 \mathrm{~nm}$ and the results expressed as $\mu$ moles ADP/ $\mathrm{mg}$ protein/hour.

\section{Statistical Analysis}

All the data are expressed as means with standard deviation (SD). Analysis the data of plasma ions, osmolality and gill NKA activity between groups was carried out using one-way analysis of variance (ANOVA) by SPSS (17) in individuals. Statistically significant differences were expressed as $p<0.05$.

\section{Ethical Statement}

The collection and use of experimental animals in this study complied with Iranian animal welfare laws, guidelines and policies, and was approved by the Gorgan University of Agricultural Sciences and Natural resources, College of Fisheries and Environment, Gorgan, Iran and the Portuguese Animal Welfare Law (Decreto-Lei no.197/96) and animal protocols were approved by CIIMAR/UP.

\section{Results}

\section{Survival}

No mortality occurred in 5 and 10 ppt of non-heat shock (NHS) treatments in first stage (Figure 1). However, after $96 \mathrm{~h}$ exposure mortality was significantly higher in 15 ppt of NHS treatments in first stage (Figure 1). There were a non-significant mortality in 5 and $10 \mathrm{ppt}$ of heat shock (HS) treatments in first stage (Figure 1). In the second stage, a significant mortality was observed in $10 \mathrm{ppt}$ of HS treatment and $15 \mathrm{ppt}$ of both NHS and HS treatments (Figure 1).

\section{Osmoregulatory Indicators: Plasma Ions and Osmolality}

Blood parameters from stages 1 and 2 are presented in Figures 2 and 3, respectively. Plasma $\mathrm{Na}^{+}$and $\mathrm{Cl}^{-}$levels increased significantly in most of treatments compared with control in first and second stages (Figures 2a, 2b, 3a and 3b) except $\mathrm{Cl}^{-}$levels in 5 and 10 ppt of fist stages (Figure $2 \mathrm{~b}$ ). Plasma $\mathrm{K}^{+}$levels were not altered by $96 \mathrm{~h}$ acclimation (first stage) to 5,10 or $15 \mathrm{ppt}$ (Figure $2 \mathrm{c}$ ) however were significantly lower following second stage except in 5 ppt of HS treatment (Figure 3c). Plasma osmolality showed an significant increase only in $15 \mathrm{ppt}$ of NHS at first stage (Figure 2d) however all of treatment in the second stage showed significant increase (Figure $3 \mathrm{~d}$ ).

Blood haematocrit showed significant increase in in 5 and $15 \mathrm{ppt}$ of NHS while there was not significant change at HS treatment at first stage (Figure 2e). The all treatments in second stage showed significant increase compare to control group (Figure $3 \mathrm{e}$ ).

\section{Gill NKA Activity}

$\mathrm{Na}^{+} / \mathrm{K}^{+}$-ATPase activity in gill was rather similar to the initial levels in the FW control treatment after 96 exposures in 5, 10 or 15 ppt and only HS treatment at 10 ppt showed significant increase in first stage (Figure 2f). At the second stage (192 h), only 10 ppt of NHS showed a significant increase in gill NKA activity compared with the control group (Figure 3f). In NHS treatment, 5 and $10 \mathrm{ppt}$ showed higher NKA activity rather than 15 ppt while in HS treatment NKA activity of individuals at 15 ppt was higher than 5 ppt (Figure $3 \mathrm{f}$ ). In each salinity, NKA activity of 5 and 10 ppt at NHS were higher than HS treatments while it was inverse at $15 \mathrm{ppt}$ (Figure 3f).

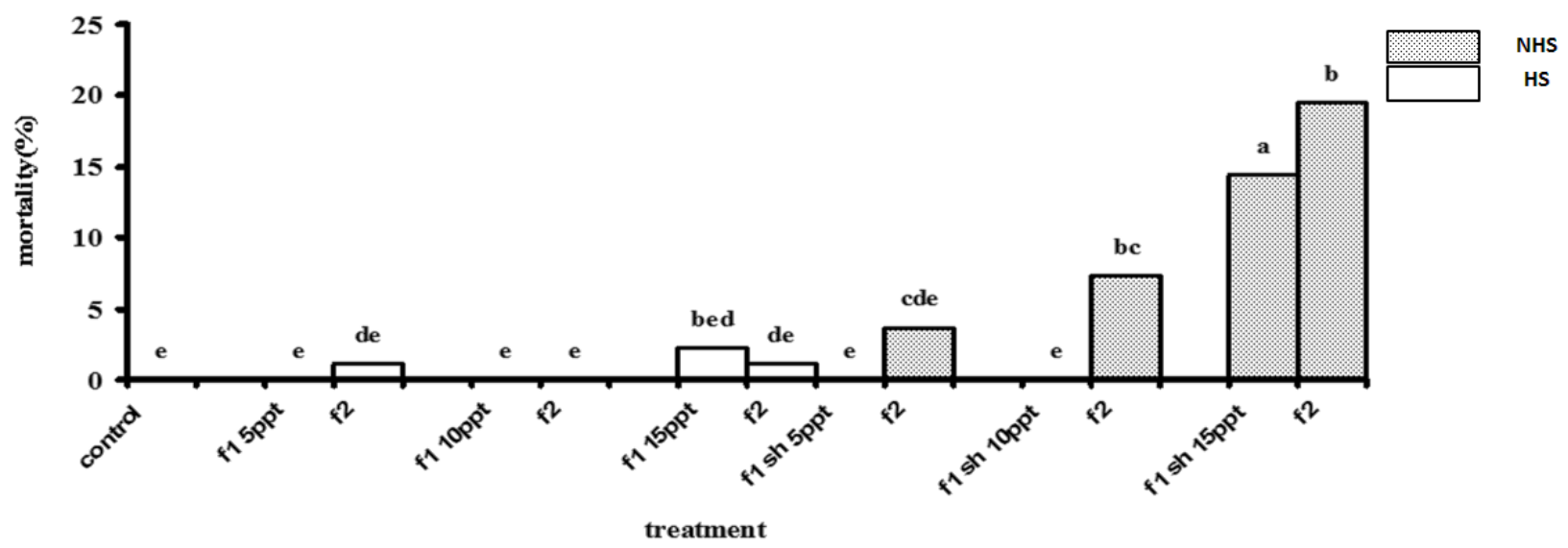

Figure 1: Mortality percentage of R. caspicus in the first ( $96 \mathrm{~h}$ ) and second stages (192 h), dotted bars, of salinity acclimation in 5, 10 and 15 ppt with (HS) and non-heat shock (NHS). Values are means + s.d. $(\mathrm{n}=6)$. Bars with the same lower case letters are not significantly different from each other $(P<0 \cdot 05)$. 


\section{First stage}

a
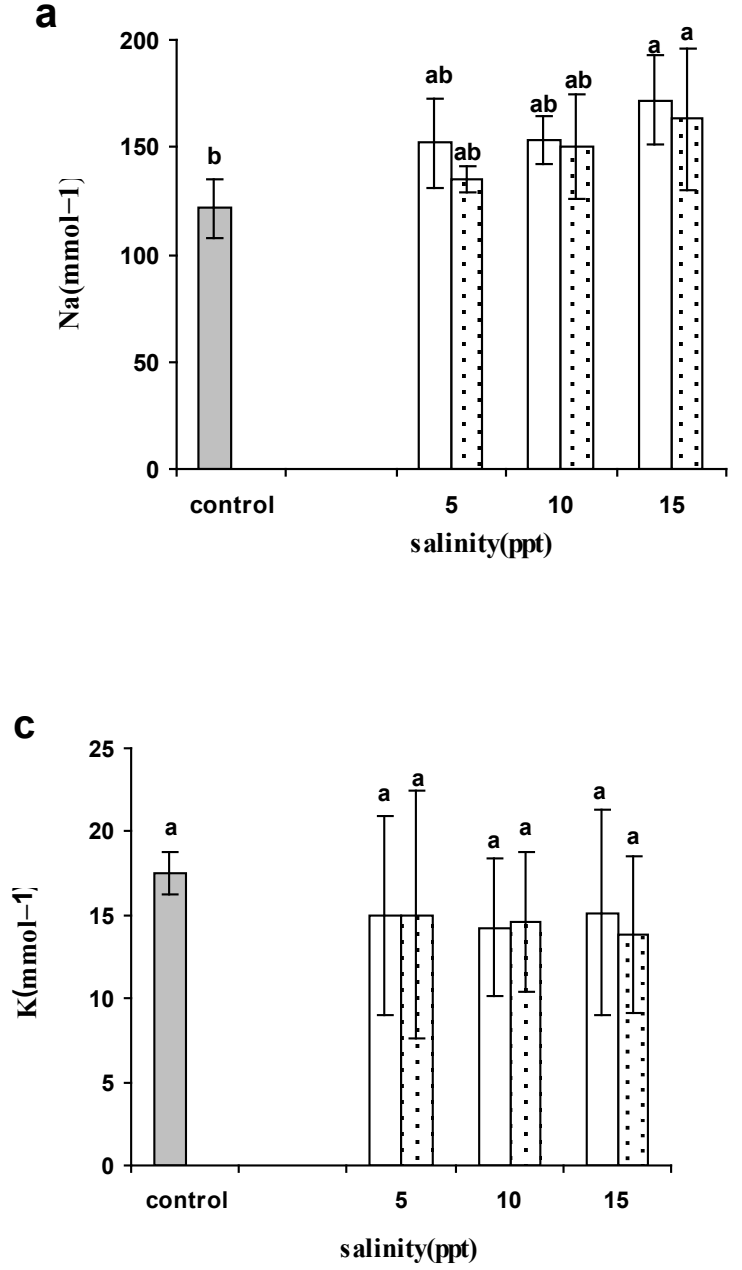

e

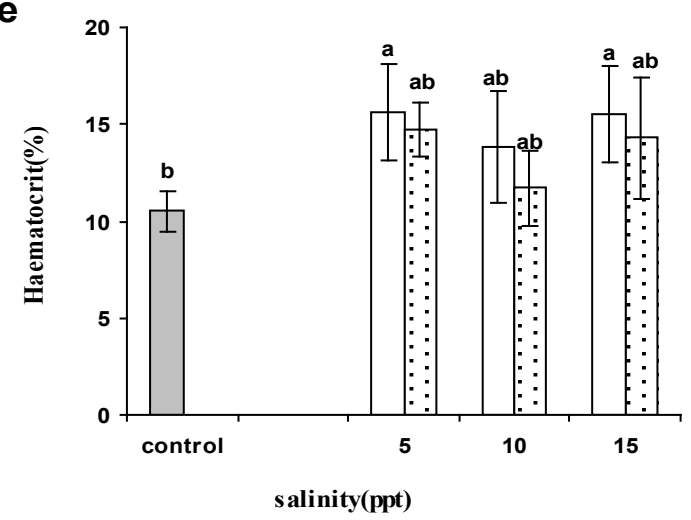

b

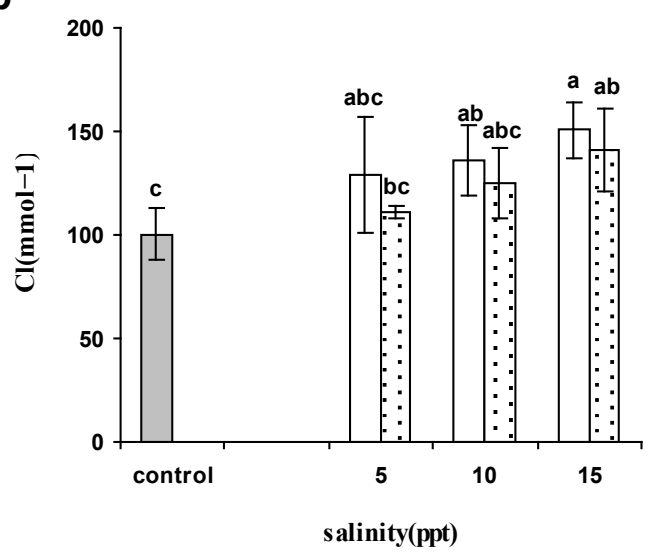

$\square$ nhs

$\square$ hs

d

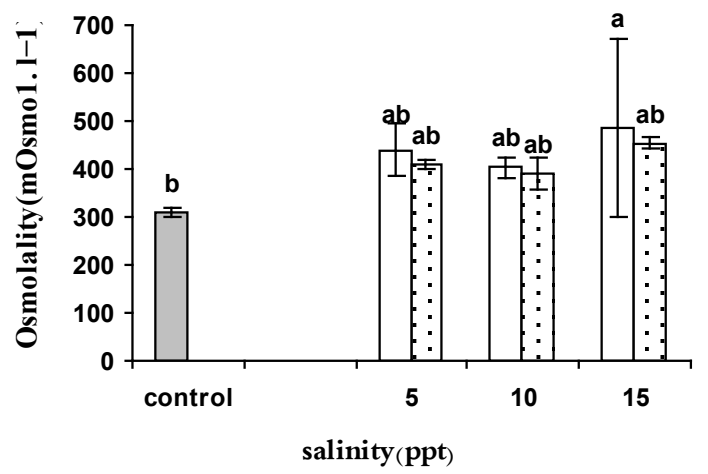

$\square$ nhs

$\square$ hs

f

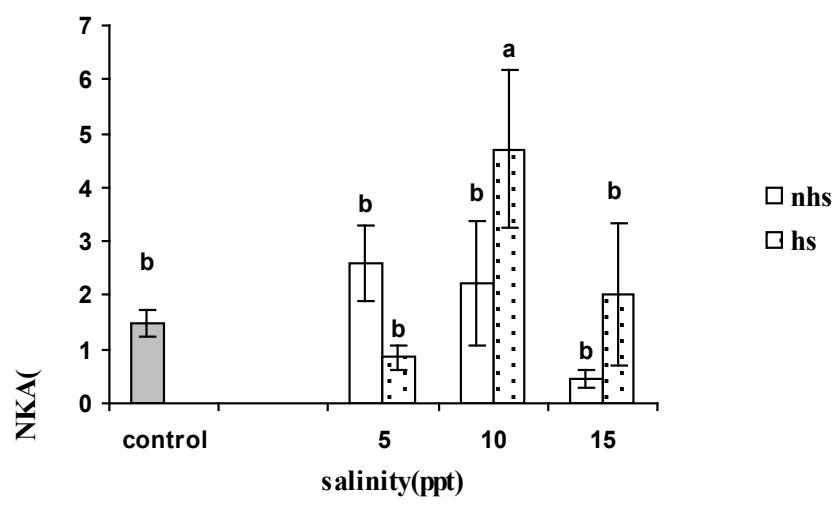

Figure 2: Plasma (a) sodium, (b) chloride and (c) potassium concentrations (mEq.1-1), (d) osmolality (mosmo.kg $\left.{ }^{-1}\right)$ and (e) haematocrit $(\%)$ as well as $(\mathrm{f})$ gill Na ${ }^{+} / \mathrm{K}^{+}-\mathrm{ATPase}$ activity $(\mu \mathrm{moles}$ $\mathrm{ADP} / \mathrm{mg}$ protein/hour) of R. caspicus transferred from 0 to 5,10 and $15 \mathrm{ppt}$ and acclimated for $96 \mathrm{~h}$ at each salinity, first stage. Dotted bars represent heat shock (HS) treatment. Values are means \pm S.E.M. ( $\mathrm{n}=6$ whole times). Bars with the same lower case letters are not significantly different from each other $(P<0.05)$. 


\section{Second stage}

a

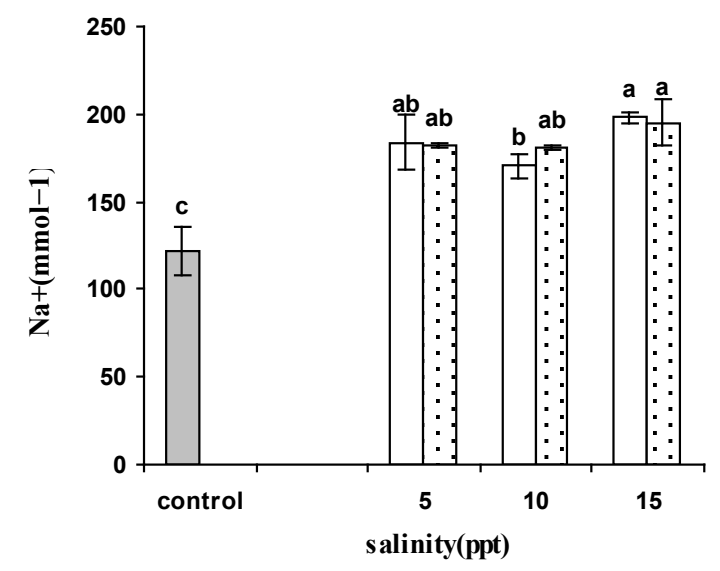

C

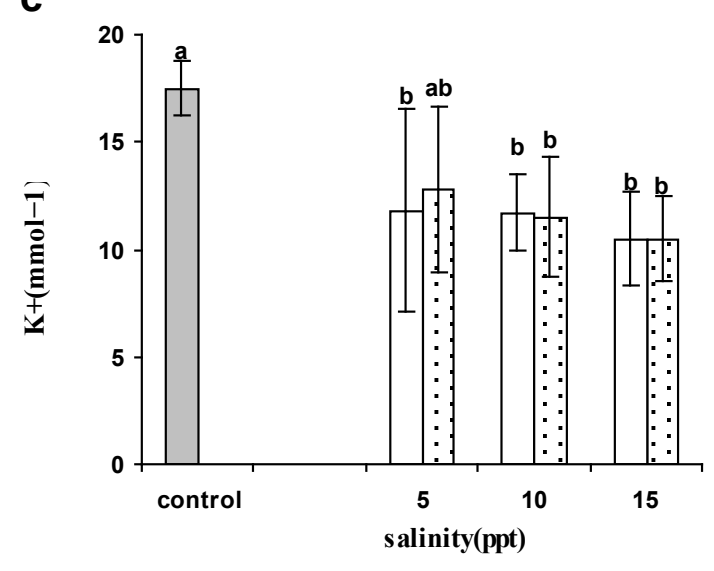

e

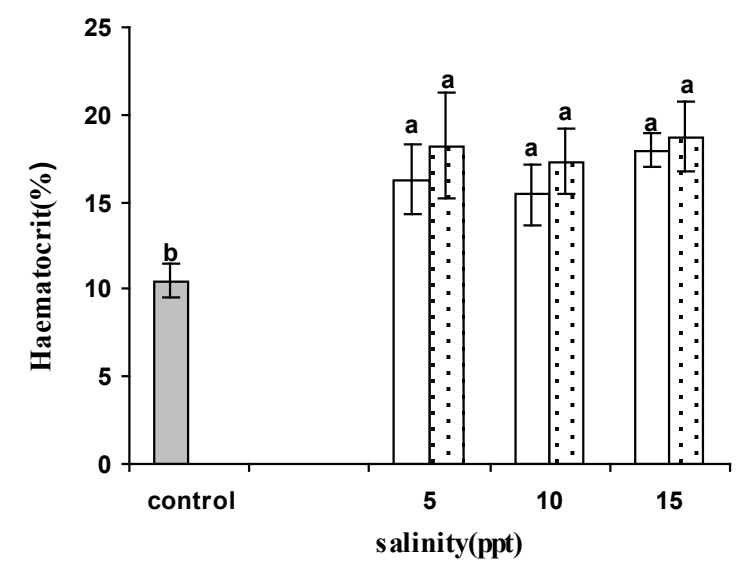

b

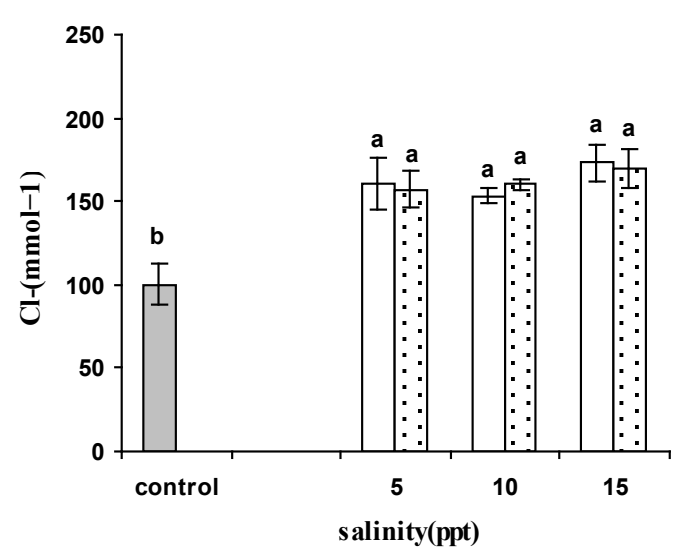

d

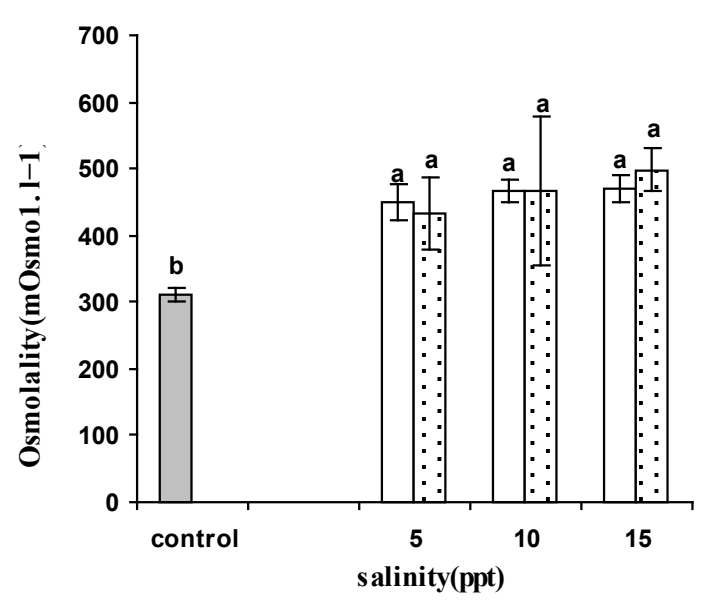

$\square$ nhs

$\square$ hs

$\square$ nhs

$\square$ hs

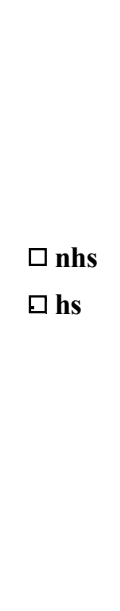

f

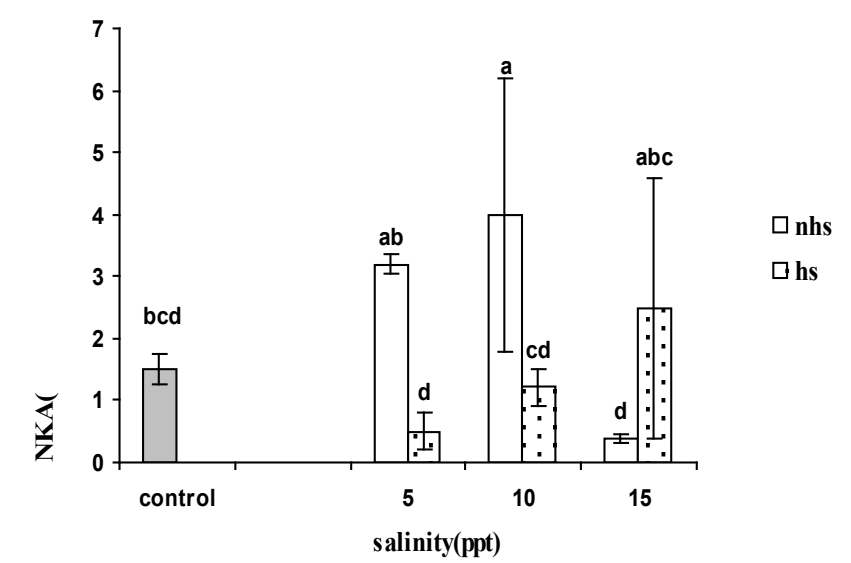

Figure 3: Plasma (a) sodium, (b) chloride and (c) potassium concentrations (mEq.1 $\left.{ }^{-1}\right)$, and (d) osmolality (mosmo.kg $\left.{ }^{-1}\right)$ and (e) haematocrit $(\%)$ as well as $(\mathrm{f})$ gill Na ${ }^{+} / \mathrm{K}^{+}$-ATPase activity $(\mu$ moles $\mathrm{ADP} / \mathrm{mg}$ protein/hour) of R. caspicus transferred from first stage ( 0 to 5,10 and $15 \mathrm{ppt}$ ) to second stage ( $15 \mathrm{ppt})$ and acclimated for second $96 \mathrm{~h}(192 \mathrm{~h})$ at given salinity ( 5,10 and $15 \mathrm{ppt})$. Dotted bars represent heat shock (HS) treatment. Values are means \pm S.E.M. ( $\mathrm{n}=6$ whole times). Bars with the same lower case letters are not significantly different from each other $(P<0.05)$. 


\section{Discussion}

Acclimated R. caspicus to higher salinity had higher plasma osmolality and ions (except $\mathrm{K}^{+}$), and hematocrit. Salinity of 5 and $10 \mathrm{ppt}$ represents the more natural salinity range of Caspian roach. However, acclimation to $15 \mathrm{ppt}$ has allowed us to test the osmoregulatory abilities of $R$. caspius under more challenging conditions. In the first stage, the direct transfer to 5 and 10 ppt in both NHS and HS treatments resulted to no mortality which might indicate relative ability of Caspian roach to tolerate such environmental condition changes. However, the observed mortality in 15 ppt of NHS and/or HS treatment might express imposed stress due to synergism effect of stressors. In NHS, two times increase in gill NKA found in $10 \mathrm{ppt}$ after transferring from first to second stage which might be contributed to rather intermediate salinity at first stage then increase positively with salinity at the second stage. In HS treatment, detected higher gill NKA at 10 ppt at first stage might be related to the stress of HS and requiring stabilizing the energy consuming then reduced to the half in second stage as regulatory period. Changes in plasma osmolality and electrolytes in HS treatment were more less similar to NHS treatment which might be occurring of initial dehydration. However, it seems that HS and salinity changes have some physiological effects on ion regulation in this fish. Together, these data representing disturbances from an internal fluid shift potentially due to water loss and elevated plasma osmolality which may be problematic resulting in a stress situation and mortality.

\section{Survival}

The observation of no mortality duration of direct transfer to 5 and $10 \mathrm{ppt}$ in both NHS and HS treatments at the first stage, indicating relative ability of this fish to tolerate such salinity changes. [32] expressed the metabolic cost of osmoregulation is reduced in brackish water (BW), because the blood-medium osmotic gradient is minimal. In contrast, gradual transfer of Caspian roach to different salinities (5, 10 or 15 ppt) resulted no mortality [10]. The goldfish Carassius auratus (L. 1758) showed high survival under chronic exposure to salinities of 5 and 10 ppt while significant mortality was observed at salinities of 15 and 20 ppt [33]. Such observation might be related to different level of endocrine and ionoregulatory pathways developing, as has been suggested in some works [34] on smoltification in salmonids or due to social hierarchies, which can also influence ionoregulatory capacity [35] and also change in chloride cells morphology and restoration of homeostasis [36,37]. The direct transferring of Common carp, Cyprinus carpio (L.). to environmental salinity (2.5, 5, and $7.5 \%$ ) showed a great adaptation and higher survival rate [38]. [39] reported survival rates of lake trout (S. namaycush), brook trout (S. fontinalis) and Atlantic salmon (Salmo salar) were $80 \%, 50 \%$ and $100 \%$, respectively following direct transferring to $30 \mathrm{ppt}$. [40] reported direct transfer of FW-adapted white sturgeon juveniles from FW to 16 ppt was associated with 25 to $30 \%$ mortality, indicating that these fish have some ability to tolerate large changes in salinity for up to 5 days. [32] reported Nile tilapia, Oreochromis niloticus, which were transferred directly to full strength SW (36 ppt) for 14 days whole mortality occurred in this period. However, O. mossambicus and its hybrids showed not survive by direct transfer to salinities of $35 \mathrm{psu}$
$[25,41]$. The observed mortalities in 15 ppt of NHS treatments might be related to osmotic shock of direct transfer to this salinity and also delay in gill NKA activation in response to osmotic challenge that is proposed to reflect changing gene expression but also transcript expression and protein synthesis [42-45]. In second stage, both treatments of $15 \mathrm{ppt}$ showed mortality (15-20\%) which might be indicted to imposed stress because of HS and subsequent apoptosis [46] and also osmotic challenge of transferring to this salinity on the other word synergism effect of stressors.

\section{Osmoregulatory Indicators: Plasma Ions and Osmolality}

Salinity challenges typically alter plasma osmolality and electrolytes levels in euryhaline teleosts with an initial crisis stage followed by a regulatory stage $[7,10,11,12,20]$. The observed plasma ion concentrations were in the range of other teleost fish species [47]; see reviews by [48]. The elevated plasma osmolality, and electrolytes (except plasma $\mathrm{K}^{+}$) of Caspian roach in the most treatments of both stages might be contributed to the occurring of initial dehydration due to osmotic efflux of water from the fish by osmosis and diffusional ion influx of electrolytes from the environment [39,45,49]. Blood osmolality in teleost fish is $280-360 \mathrm{mmol} \mathrm{kg}^{-1}$, and is tightly regulated in a species-dependent range of salinities [15]. In present study based on comparison to euryhaline fish, the values of $\mathrm{Na}^{+}, \mathrm{Cl}^{-}$and osmolality are relatively high suggesting that the fish have relatively poor salinity tolerance, or that they are in a temporary state of ion imbalance. Also increased levels of electrolytes concentrations had not returned to initial concentration (control treatment) as has been reported in [50]. The rather similar results observed in gradual transferring of Caspian roach to different salinity levels (5, 10 or $15 \mathrm{ppt}$ ) [10].

In general changes in hematology can be explained by changes in ionoregulatory status [40] and it is one of the secondary stress responses in fish [51,52]. Hematocrit showed a positive correlation with salinity in both stages, as has been reported by (Platichthy flesus: [53]; Gymnocypris przewalskii: [10,20,54,55] and in most anadromous teleosts studied to date (Oncorhynchus mykis: [56]; O. tshawytscha: [57]; S. salar: [58]) or sturgeon (Acipenser oxyrinchus, A. brevirostrum: Baker et al., 2005). By attention to previous finding which indicating to the important role of effective hormones such as cortisol, prolactin, in acclimation phase to osmotic and environmental challenges (several hours to several days after stress) [8], this result might be interpreted by measuring hormonal changes but not done in the present study thus measuring hormones which are involving in response to environmental challenges could be helpful in future study.

\section{Gill $\mathrm{Na}^{+} / \mathrm{K}^{+}$-ATPase Activity}

The assessment of osmoregulatory status/ability of teleosts has been achieved by using the branchial NKA activity responses (mRNA and protein expression) [1,59]. The alterations in gill NKA activity in relation to environmental salinity are diverse, but two typical situations seem to prevail: (i) a direct relationship, characteristic of anadromous species, in which higher salinities induce higher values of NKA activity [60] and (ii) a U-shaped relationship, described for some euryhaline teleosts, in which lower values of NKA activity occur at intermediate salinities and higher values at low and high salinities [10,11,45,61-63]. There are 
various reports which express/state no effect of salinity on NKA activity (Gillichthys mirabilis: [64]), conversely, strong effect of medium salinity on gill NKA activity (Scophthalmus maximus: [65]), positive correlation between environmental salinity and NKA activity (Oreochromis mossambicus: [66]; Onchorhynchus keta: [67]) and negative correlation (F. heteroclitus: [68]; O. mossambicus: [20,69]). Short- and long term acclimation to environmental salinity have examined intermediate metabolism changes in euryhaline fishes [70-74]. Gaumet et al. (1995) suggested that NKA activity is generally lowest in fish living in a medium whose salinity is equivalent to that of the blood. An ecologically theory would state that fish would be adapted to spend the least amount of osmoregulatory energy in environmental salinities they evolved to live in. Also, physiologically we would expect the energy consuming NKA activity to be minimal at environmental salinities isosmotic to blood $[10,75]$. According our results most changes occurred in 10 ppt of NHS treatments (Figure 2f). The observed two times increase in gill NKA of $10 \mathrm{ppt}$ after transferring from the first to second stage (15 ppt) might be contributed to rather intermediate salinity at first stage then increase positively with salinity at second stage. Adaptation of Caspian roach individuals to different salinity presumably can be results increasing the number of entering ions to the body thus occurring water loss by osmosis. In continue, increasing/or tendency to increase in gill NKA activity occurring to absorb water from the external environment [21] however, decreased significantly at the salinity of $15 \mathrm{ppt}$. The latter might be due to the increase of plasma $\mathrm{Na}^{+}$and $\mathrm{Cl}^{-}$as the major electrolytes in the body fluid and their critical role in osmoregulation [59] which result to increase plasma osmolality under higher salinity condition thus decrease of NKA activity. The similar results have been reported in the juvenile largemouth bass adapted to saline waters [21] and Mozambique tilapia [76]. In juvenile turbot (Scophthalmus maximus) reduced gill NKA activity at $15 \%$ salinity levels would lead to reduced energy expenditures [65]. In another experiment, gill NKA activity of Caspian roach decreased with salinity in the short term with activity being the lowest in fish kept $48 \mathrm{~h}$ at $15 \mathrm{ppt}$ although with longer acclimation $(+96 \mathrm{~h})$ returned to control levels [10]. Furthermore, the results of this study might be indicating that Caspian roach are a bit intolerant of salinity. Some studies revealed that the source of changing NKA activity upon salinity challenge might be alterations on mRNA level [43,77], or protein level (O. mossambicus: $[78,79]$, or both levels [80]; O. mossambicus: [69]). In general, related to the effect of abrupt transfer to different salinities on physiologic /osmoregulatory functions more studies are required. Perhaps, Caspian roach like salmonids, anadromous species, [45] activation of gill NKA takes place 3-7 days after transfer to higher salinity or that $15 \mathrm{ppt}$ is just not enough salinity to induce increases. It would be of interest to see if the fish can survive long term exposure ( 2 weeks or more) to $15 \mathrm{ppt}$ (or more) and what the levels of plasma ions and gill NKA activity are after this acclimation.

\section{Heat Shock (HS)}

The ambient temperature can effect on the internal ionic and osmotic balance of fish $[17,24,81,82]$. Rapid temperature changes, heat or cold shocks, are among the stressors with a high physiological impact on fish $[83,84]$. Changes in plasma osmolality and electrolytes in HS treatment were more less similar to NHS treatment which might be occurring of initial dehydration. A reduction was observed in plasma $\mathrm{K}^{+}$level accompanied by salinity increase in the second stage. It has been shown that in SW the fish gills are permeable to $\mathrm{K}^{+}$ that efflux is greater than influx [85]. This would indicate that reduced uptake, rather than increased loss of $\mathrm{K}^{+}$, is the more important factor contributing to the poor performance of fish $[10,86]$. Also, change in gill NKA activity [45] and passive efflux of $\mathrm{K}^{+}$from kidney segments [87] can be potential reasons for such reduction. After exposure of $R$. caspicus to short term increasing temperature condition, ascending trend in first stage and significant increase of plasma osmolality at second stage were found (Figure $2 \mathrm{~d}$ and $3 \mathrm{~d}$ ). Even though the gill NKA was not affected (Figure 2f). Moreover, NKA activity was assayed at the higher level than exposure temperature of the fish that might show the apparent NKA activity not provide a physiological interpretation of our results. The protein conformation, kinetic properties, and assembly can be affected by influencing of temperature on the reactivity of molecules [88]. The activation of ion transporter system is energy-required while the main process for energy providing, the rate of cellular respiration, is temperature-dependent [89]. Therefore, detected higher gill NKA at $10 \mathrm{ppt}$ at first stage might be related to the stress of $\mathrm{HS}$ and requiring stabilizing the energy consuming then reduced to the half in second stage as regulatory period (Figure 2f) which potentially reflected that metabolically-dependency of ion transporter proteins to temperature change rather susceptible to passive ion diffusion [89-92]. Furthermore, inhabitation of specific activity of NKA by temperature was found in the Mozambique tilapia and common carp [88]. It was found that a lower apparent NKA activity was compensated by strongly enhanced NKA expression $[17,24]$. The present study was difficult to rule out the possibility of heat shock having much of an impact on overall ion regulation although clear responses to salinity can be found. Study on the heat shock proteins (HSP70, 90) by suing immunoblotting and gene expression (PCRqPCR) considering response to the environmental stress such as heat shock or salinity changes, measurement the plasma cortisol, lactate and glucose might be interest for future works.

\section{Conclusion}

It seems that Caspian roach juveniles need to complete ionosmo regulation systems for adaptation with BW and biochemistryphysiologic parameters of juveniles are determinant their adjustment to the natural conditions. According the management point of view, it seems that HS and salinity changes have some physiological effects concern ion regulation in this fish. Although for more confidence, study various salinities, different time of sampling and other environmental tolerances such as temperature, culture density, diet and also focus on the expression patterns of ion transporters such as $\mathrm{NKA}, \mathrm{Na}^{+} / \mathrm{K}^{+} / 2 \mathrm{Cl}^{-}$ (NKCC), cystic fibrosis transmembrane conductance regulator (CFTR, chloride channel), V-ATPase proton pump in the gills, kidney and digestive tract $[24,55]$ are needed.

\section{Acknowledgments}

The study was supported by the University of Gorgan. We are very grateful to Mrs. Yalda Sheikh for assistance in preparation of solutions. We would also like to thank Dr. Stephen McCormick and Dr. Vahid Khori for their advises and comments. We would like to thank anonymous referees for comments on an earlier version of the manuscript. 


\section{References}

1. Hwang PP, Lee TH (2007) New insights into fish ion regulation and mitochondrionrich cells. Comparative Biochemistry and Physiology - Part A: Molecular \& Integrative Physiology 148: 479-497. [crossref]

2. Edwards SL, Marshall WS (2012) Principles and patterns of osmoregulation and euryhalinity in fishes," in SC McCormick, AP Farrell, CJ Brauner (eds.) Fish Physiology-Euryhaline Fishes (London: Academic Press) 32: 1-44.

3. Hiroi J, Yasumasu S, McCormick SD, Hwang PP, Kaneko T (2008) Evidence for an apical $\mathrm{Na}-\mathrm{Cl}$ cotransporter involved in ion uptake in a teleost fish. Journal of Experimental Biology 211: 2584-2599. [crossref]

4. Marshall WS, Grosell M (2006) Ion transport, osmoregulation and acid-base balance," in (Eds.), DH Evans and JB Claiborne. The Physiology of Fishes (Boca Raton, FL: CRC Press), 177-230.

5. Schultz ET, McCormick SD (2013) Euryhalinity in an evolutionary context. In SD McCormick, AP Farrell, CJ Brauner (EDs.). Fish Physiol. 32. Academic Press, pp. 477-533.

6. Takei Y, Hwang PP (2016) Homeostatic Responses to Osmotic Stress. In: CB Schreck, L Tort, AP Farrell, CJ Brauner (Eds.) Fish Physiology-Biology of stress in fish. 35 Academic Press Inc San Diego, United States Elsevier 208-237.

7. Wang PJ, Lin CH, Hwang LY, Huang CL, Lee TH, et al. (2009) Differential responses in gills of euryhaline tilapia, Oreochromis mossambicus, to various hyperosmotic shocks. Comparative Biochemistry and Physiology - Part A: Molecular \& Integrative Physiology 152: 544-551. [crossref]

8. McCormick SD, Bradshaw D (2006) Hormonal control of salt and water balance in vertebrates. General Comparative Endocrinology 147: 3-8. [crossref]

9. Evans DH, Piermarini PM, Choe KP (2005) The multifunctional fish gill: dominant site of gas exchange, osmoregulation, acid-base regulation, and excretion of nitrogenous waste. Physiological Review 85: 97-177. [crossref]

10. Malakpour Kolbadinezhad S, Hajimoradloo A, Ghorbani R, Joshaghani H, Wilsonm JM (2012) Effects of gradual salinity increase on osmoregulation in Caspian roach Rutilus caspicus. Journal of Fish Biology 81: 125-134. [crossref]

11. Jensen MK, Madsen SS, Kristiannsen K (1998) Osmoregulation and salinity effects on the expression and activity of $\mathrm{Na}+/ \mathrm{K}+$-ATPase in gills of European sea bass (Dicentrachus labrax) L. Journal of Experimental Zoology 282: 290-300.

12. Madsen SS, Naamansen ET (1989) Plasma ionic regulation and gill $\mathrm{Na}+\mathrm{K}+-$ ATPase changes during rapid transfer to sea water of yearling rainbow trout (Salmo gairdneri): time course and seasonal variation. Journal of Fish Biology 34: 829-840.

13. Berge AI, Berg A, Fyhn HJ, Barnung T, Hansen T, et al. (1995) Development of salinity tolerance in underyearling smolts of Atlantic salmon (Salmo salar) reared under different photoperiods. Canadian Journal of Fisheries and Aquatic Sciences 52: 243-251.

14. Mancera JM, McCormick SD (2000) Rapid activation of gill Na+/K+-ATPase in the euryhaline teleost (Fundulus heteroclitus). Journal of Experimental Zoology 287: 263274. [crossref]

15. Varsamos S, Wendelaar Bonga SE, Charmantier G, Flik G (2004) Drinking and Na+/ $\mathrm{K}+$-ATPase activity during early development of European sea bass (Dicentrarchus labrax): ontogeny and short-term regulation following acute salinity changes. Journal of Experimental Marine Biology and Ecology 311: 189-200.

16. Kang CK, Tsai SC, Lee TH, Hwang PP (2008) Differential expression of branchial $\mathrm{Na}+/ \mathrm{K}+$-ATPase of two medaka species, Oryzias latipes and Oryzias dancena, with different salinity tolerances acclimated to fresh water, brackish water and seawater. Comparative Biochemistry and Physiology 151: 566-575.

17. Sardella BA, Kültz D, Cech J Jr, Brauner C (2008a) Salinity-dependent changes in $\mathrm{Na}+\mathrm{K}+$-ATPase content of mitochondria-rich cells contribute to differences in thermal tolerance of Mozambique tilapia. Journal of Comparative Physiology 178: 249-256.

18. Christensen AK, Hiroi J, Schultz ET, McCormick SD (2012) Branchial ionocyte organization and ion-transport protein expression in juvenile alewives acclimated to freshwater or seawater. Journal of Experimental Biology 215: 642-652. [crossref]

19. Tait JC, Mercer Evan W, Gerber L, Robertson GN, Marshall WS (2017) Osmotic versus adrenergic control of ion transport by ionocytes of Fundulus heteroclitus in the cold. Comp Biochem Physiol A Mol Integr Physiol 203: 255-261. [crossref]
20. Malakpour Kolbadinezhad S, Coimbra J, Wilson JM (2018a) Osmoregulation in the Plotosidae catfish: role of the salt secreting dendritic organ. Frontiers in Physiology 9: 761 .

21. Yi H, Chen X, Liu S, Han L, Liang J, et al. (2021) Growth, osmoregulatory and hypothalamic-pituitary-somatotropic (HPS) axis response of the juvenile largemouth bass (Micropterus salmoides), reared under different salinities Aquaculture Reports 20.

22. Somero GN (2010) The physiology of climate change: how potentials for acclimatization and genetic adaptation will determine 'winners' and 'losers'. Journal of Experimental Biology 213: 912-920.

23. Long Y, Li L, Li Q, He X, Cui Z (2012) Transcriptomic characterization of temperature stress responses in larval zebrafish. PLoS ONE 7: 37209. [crossref]

24. Metz JR, van der Burg EH, Wendelaar-Bonga SE, Flik G (2003) Regulation of branchial $\mathrm{Na}+/ \mathrm{K}+$-ATPase in common carp Cyprinus carpio acclimated to different temperatures. Journal of Experimental Biology 206: 2273-2280. [crossref]

25. Sardella BA, Matey V, Cooper J, Gonzalez RJ, Brauner CJ (2004) Physiological biochemical and morphological indicators of osmoregulatory stress in 'California Mozambique tilapia (Oreochromis mossambicus x O. urolepis hornorum) exposed to hypersaline water. Journal of Experimental Biology 207: 1399-1413. [crossref]

26. Crockett EL, Londraville RL (2006) Temperature, in: Evans DH, Claiborne JB (Eds.), The Physiology of Fishes, Marine Biology Series. CRC, Taylor \& Francis, Boca Raton, 497 FL 231-269.

27. Sattari M (2002) Ichtiology (1), Anatomy and Physiology. Gilan University Publication. 378p (in Persian).

28. Keyvanshokooh S, Ghasemi A, Shahriari-Moghadam M, Nazari RM, Rahimpour M (2007) Genetic analysis of Rutilus rutilus caspicus (Jakowlew 1870) populations in Iran by microsatellite markers. Aquaculture Research 38: 953-956.

29. Kiabi BH, Abdoli A, Naderi M (1999) Status of the fish fauna in the South Caspian basin of Iran. Zoology in the Middle East 18: 57-65.

30. Biswas AK, Seoka M, Takii K, Maita M, Kumai K (2006) Stress response of red sea bream (Pagrus major) to acute handling and chronic photoperiod manipulation. Aquaculture 252: 566-572.

31. Wilson JM, Leitão A, Gonçalves AF, Ferreira C, Reis-Santos P (2007) Modulation of branchial ion transporter protein expression by salinity in glass eels Anguilla anguilla L. Marine Biology 151: 1633-1645.

32. Guner Y, Ozden O, Cagiran H, Altunko M, Kizak V (2005) Effect of salinity on the osmoregulation function of the gill in Nile tilapia (Orechormic niluticus). Turk. J. Vet. Anim. Sci 29: 1259-1266.

33. Schofield PJ, Brown ME, Fuller PL (2006) Salinity tolerance of goldfish, Carassius auratus, a non-native fish in the United States. JSTOR 69: 258-268.

34. Beckman BR, Larsen DA, Dickhoff WW (2003) Life history plasticity in Chinook salmon: relation of size and growth rate to autumnal smolting. Aquaculture 222: 149165.

35. Sloman KA, Scott GR, Diao Z, Rouleau C, Wood CM, et al. (2003a) Cadmium affects the social behaviour of rainbow trout (Oncorhynchus mykiss). Aquatic Toxicology 65: 171-185. [crossref]

36. Kelly SP, Woo NYS (1999) The response of sea bream following abrupt hypoosmotic exposure. Journal of Fish Biology 55: 732-750.

37. Ouattara N, Bodinier C, Negre-Sadargues G, D’Cotta H, Messad S, et al. (2009) Changes in gill ionocyte morphology and function following transfer from fresh to hypersaline waters in the tilapia Sarotherodon melanotheron. Aquauculture 290: 155164.

38. Saravanan M, Ramesh M, Petkam R, Poopal RK (2018) Influence of environmental salinity and cortisol pretreatment on gill $\mathrm{Na}+/ \mathrm{K}+-$ ATPase activity and survival and growth rates in Cyprinus carpio. Aquaculture Reports 11: 1-7.

39. Hiroi J, McCormick SD (2007) Variation in salinity tolerance, gill Na+/K+-ATPase, $\mathrm{Na}+/ \mathrm{K}+/ 2 \mathrm{Cl}$-cotransporter and mitochondria-rich cell distribution in three salmonids (Salvelinus namaycush, Salvelinus fontinalis and Salmo salar). Journal of Experimental Biology 210: 1015-1024. [crossref]

40. Mojazi Amiri B, Baker DW, Morgan JD, Brauner CJ (2009) Size dependent early salinity tolerance in two sizes of juvenile white sturgeon (Acipenser transmontanus). Aquaculture 286: 121-126. 
41. Hwang P, Sun CM, Wu SM (1989) Changes of plasma osmolarity, chloride concentration and gill $\mathrm{Na}+\mathrm{K}+$-ATPase activity in tilapia (Oreochromis mossambicus) during seawater acclimation. Marine Biology 100: 295-299.

42. Lee TH, Hwang PP, Shieh YE, Lin CH (2000) The relationship between "deephole" mitochondria-rich cells and salinity adaptation in the euryhaline teleost (Oreochromis mossambicus). Fish Physiology and Biochemistry 23: 133-140.

43. Seidelin M, Madsen SS, Blenstrup H, Tipsmark CK (2000) Time-course changes in the expression of $\mathrm{Na}+\mathrm{K}+$-ATPase in gills and pyloric caeca of brown trout (Salmo trutta) during acclimation to seawater. Physiological and Biochemical Zoology 73: 446453. [crossref]

44. Tipsmar CK, Madsen SS, Seidelin M, Christensen AS, Cutler CP, et al. (2002) Dynamics of $\mathrm{Na}+/ \mathrm{K}+/ 2 \mathrm{Cl}$ - cotransporter and $\mathrm{Na}+/ \mathrm{K}+-\mathrm{ATPase}$ expression in the branchial epithelium of brown trout (Salmo trutta) and Atlantic salmon (Salmo salar). Journal of Experimental Zoology 293: 106-118

45. Laiz-Carrión R, Guerreiro PM, Fuentes J, Canario AVM, Martín del Río MP, et al. (2005) Branchial osmoregulatory response to salinity in the gilthead sea bream (Sparus auratus). Journal of Experimental Zoology 303: 563-576. [crossref]

46. DuBeau SF, Pan F, Tremblay GC, Bradley TM (1998) Thermal shock of salmon in vivo induces the heat shock protein (Hsp70) and confers protection against osmotic shock. Aquaculture 168: 311-323.

47. Whittamore JM (2012) Osmoregulation and epithelial water transport: lessons from the intestine of marine teleost fish. Journal of Comparative Physiology B 182: 1-39.

48. Freire CA, Prodocimo V (2007) Special challenges to teleost fish osmoregulation inenvironmentally extreme or unstable habitats. in: B Baldisserotto, JM Mancera, BG Kapoor (Eds.), Fish Osmoregulation. Science Publishers, Enfield, 249-276.

49. Fielder DS, Allan GL, Pepperalla D, Parkhurst PM (2007) The effect of changes in salinity on osmoregulation and chloride cell morphology of juvenile Australian snapper (Pagrus auratus). Aquaculture 272: 656-666

50. Martinez-Alvarez RM, Sanz A, Garcia-Gallego M, Domezain A, Domezain J, et al. (2005) Adaptive branchial mechanisms in the sturgeon (Acipenser naccarii) during acclimation to saltwater. Comp Biochem Physiol A Mol Integr Physiol 141: 183-190. [crossref]

51. Portz DE, Woodley CM, Cech Jr JJ (2006) Stress-associated impacts of short-term holding on fishes. Reviews in Fish Biology and Fisheries 16: 125-170.

52. Sopinka NM, Donaldson MR, O'Connor CM, Suski CD, Cooke SJ (2016) Stress Indicators in Fish. In: CB Schreck, L Tort, AP Farrell, CJ Brauner (Eds.) Fish Physiology - Biology of stress in fish. 35 Academic Press Inc San Diego, United States Elsevier. pp: 405-462.

53. Jensen FB, Lecklin T, Busk M, Bury NR, Wilson R, et al. (2002) Physiological impact of salinity increase at organism and red blood cell levels in European flounder (Platichthy flesus). Journal of Experimental Marine Biology and Ecology 274: 159-174.

54. Wang YS, Gonzalez RJ, Patrick ML, Grosell M, Zhang C, et al. (2003) Unusual Physioliology of scale-less carp (Gymnocypris przewalskii) in lake Qinghai: a high altitude alkaline saline lake. Comparative Biochemistry and Physiology A 134: 409421

55. Malakpour Kolbadinezhad S, Coimbra J, Wilson JM (2018b) Effect of dendritic organ ligation on striped eel catfish Plotosus lineatus osmoregulation. PLoS One 13: e0206206. [crossref]

56. Wang Y, Heigenhauser GJF, Wood CM (1994) Integrated responses to exhaustive exercise and recovery in rainbow trout white muscle: acid-base, phosphogen, carbohydrate, lipid, ammonia, fluid volume and electrolyte metabolism. Journal of Experimental Biology 195: 227-258

57. Gallaugher PE, Thorarensen H, Kiessling A, Farrell AP (2001) Effects of high intensity training on cardiovascular function, oxygen uptake, internal oxygen transport and osmotic balance in Chinook salmon (Oncorhynchus tshawytscha) during critical speed swimming. Journal of Experimental Biology 204: 2861-2872. [crossref]

58. Kieffer JD, Rossiter AM, Kieffer CA, Davidson K, Tufts BL (2002) Physiology and survival of Atlantic salmon following exhaustive exercise in hard and softer water: implications for the catch-and -release sport fishery. North American Journal of Fisheries Management 22: 132-144.

59. Kaneko T, Watanabe S, Lee KM (2008) Functional morphology of mitochondrionrich cells in euryhaline and stenohaline teleosts. Aquatic Bioscience Monographs (ABSM) 1: 1-62.
60. McCormick SD (1995) Hormonal control of gill $\mathrm{Na}+\mathrm{K}+-\mathrm{ATPase}$ and chloride cell function. In: CM Wood, TJ Shuttlewoth, (Eds.), Fish Physiology 14. San Diego, CA: Academic Press. Pp. 285-315.

61. Lisboa V, Barcarolli IF, Sampaio LA, Bianchini A (2015) Effect of salinity on survival, growth and biochemical parameters in juvenile Lebranch mullet Mugil liza (Perciformes: Mugilidae). Neotropical Ichthyology 13: 447-452.

62. Zhang YT, Huang S, Qiu HT, Li Z, Mao Y, et al. (2017) Optimal salinity for rearing Chinese black sleeper (Bostrychus sinensis) fry. Aquaculture 476: 37-43.

63. Liu B, Guo HY, Zhu K, Guo L, Liu B, et al. (2019) Growth, physiological, and molecular responses of golden pompano Trachinotus ovatus (Linnaeus, 1758) reared at different salinities. Fish Physiology and Biochemistry 45: 1879-1893. [crossref]

64. Yoshikawa JSM, McCormick SD, Young G, Bern HA (1993) Effects of salinity on chloride cells and $\mathrm{Na}+/ \mathrm{K}+$-ATPase activity in the teleost (Gillichthys mirabilis). Comp Biochem Physiol Comp Physiol 105: 311-317. [crossref]

65. Imsland AK, Gunnarsson S, Foss A, Stefansson SO (2003) Gill Na+/K+-ATPase activity, plasma chloride and osmolality in juvenile turbot (Scophthalmus maximus) reared at different temperatures and salinities. Aquaculture 218: 671-683.

66. Kültz D, Bastrop R, Jürss K, Siebers D (1992) Mitochondria-rich (MR) cells and the activities of the $\mathrm{Na}+\mathrm{K}+$-ATPase and carbonic anhydrase in the gill and opercular epithelium of (Oreochromis mossambicus) adapted to various salinities. Comparative Biochemistry and Physiology 102: 293-301.

67. Uchida K, Kaneko T, Yamauchi K, Ogasawara T, Hirano T (1997) Reduced hypoosmoregulatory ability and alteration in gill chloride cell distribution in mature chum salmon (Onchorhynchus keta) migrating upstream for spawning. Marine Biology 129: 247-253.

68. Marshall WS, Emberley TR, Singer TD, Bryson SE, McCormick SD (1999) Time course of salinity adaptation in a strongly euryhaline estuarine teleost (Fundulus heteroclitus): a multivariable approach. Journal of Experimental Biology 202: 15351544. [crossref]

69. Lin CH, Huang CL, Yang CH, Lee TH, Hwang PP (2004) Time-course changes in the expression of $\mathrm{Na}+/ \mathrm{K}+$-ATPase and the morphometry of mitochondrion-rich cells in gills of euryhaline tilapia (Oreochromis mossambicus) during freshwater acclimation. Journal of Experimental Zoology 301: 85-96. [crossref]

70. Sangiao-Alvarellos S, Laiz-Carrion R, Guzman JM, Martın del Rio MP, Mancera JM, et al. (2003) Acclimation of Sparus aurata to various salinities alters energy metabolism of osmoregulatory and nonosmoregulatory organs. American Journal of Physiology 285: 897-907. [crossref]

71. Sangiao-Alvarellos S, Arjona FJ, Martín del Río MP, Míguez JM, Mancera JM, et al. (2005). Time course of osmoregulatory and metabolic changes during osmotic acclimation in Sparus auratus. Journal of Experimental Biology 208: 4291-4304. [crossref]

72. Arjona FJ, Vargas-Chacoff L, Ruiz-Jarabo I, Martin del Rio MP, Mancera JM (2007) Osmoregulatory response of Senegalase sole (Solea senegalensis, Kaup 1858) to changes in auratus L., a non-native fish in the United States. Florida Scientist 69: 258-268.

73. Herrera M, Vargas-Chacoff L, Hachero I, Rui'z-Jarabo I, Rodiles A, et al. (2009) Osmoregulatory changes in wedge sole (Dicologoglossa cuneata, Moreau 1881) after acclimation to different environmental salinities. Aquaculture Research 40: 762-771.

74. Vargas-Chacoff L, Arjona FJ, Polakof S, Martin del Rio MP, Soengas JL, et al. (2009) Interactive effects of environmental salinity and temperature on metabolic responses of gilthead sea bream Sparus aurata. Comparative Biochemistry and Physiology A Mol Integr Physiol 154: 417-424. [crossref]

75. Saoud IP, Kreydiyyeh S, Chalfoun A, Fakih M (2007) Influence of salinity on survival, growth, plasma osmolality and gill $\mathrm{Na}+\mathrm{K}+$-ATPase activity in the rabbit fish (Siganus rivalatus). Journal of Experimental Marine Biology and Ecology 348: 183-190.

76. Vonck APMA, Wendelaar Bonga SE, Flik G (1998) Sodium and calcium balance in Mozambique tilapia, Oreochromis mossambicus, raised at different salinities. Comp Biochem Physiol A Mol Integr Physiol 119: 441-449. [crossref]

77. Scott GR, Richards JG, Forbush B, Isenring P, Schulte PM (2004) Changes in gene expression in gills of the euryhaline killifish (Fundulus heteroclitus) after abrupt salinity transfer. American Journal of Physiology 287: 300-309. [crossref]

78. Lee TH, Feng SH, Lin CH, Hwang YH, Huang CL, et al. (2003) Ambient salinity modulates the expression of sodium pumps in branchial mitochondria-rich cells of Mozambique tilapia (Oreochromis mossambicus). Zoological Science 20: 29-36. [crossref] 
79. Lin YM, Chen CN, Lee TH (2003) The expression of gill Na+/K+-ATPase in milkfish (Chanos chanos) acclimated to seawater, brackish water and fresh water. Comparative Biochemistry and Physiology A Mol Integr Physiol 135: 489-497. [crossref]

80. D'Cotta H, Valotaire C, Le Gac F, Prunet P (2000) Synthesis of gill Na+/K+-ATPase in Atlantic salmon smolts: differences in a-mRNA and a-protein levels. American Journal of Physiology 278: 101-110. [crossref]

81. Fiess JC, Kunkel-Patterson A, Mathias L, Riley LG, Yancey PH, et al. (2007) Effects of environmental salinity and temperature on osmoregulatory ability, organic osmolytes, and plasma hormone profiles in the Mozambique tilapia (Oreochromis mossambicus). Comparative Biochemistry and Physiology - Part A: Molecular \& Integrative Physiology 146: 252-264. [crossref]

82. Sardella BA, Sanmarti E, Kültz D (2008b) The acute temperature tolerance of green sturgeon (Acipenser medirostris) and the effect of environmental salinity. Journal of Experimental Zoology. A. Ecol genet Physiol 309: 477-483. [crossref]

83. Crawshaw LI (1979) Responses to rapid temperature change in vertebrate ectotherms. Ameriacn Zoology 19: 225-237.

84. Tanck MWT, Booms GHR, Eding EH, Bonga SEW, Komen J (2000) Cold shocks: a stressor for common carp. Journal of Fish Biology. 57: 881-894.

85. Sanders MJ, Kirschner LB (1983) Potassium metabolism in seawater teleosts II. Evidence for active potassium transport extrusion across the gill. Journal of Experimental Biology 104: 29-40.
86. Partridge GJ, Lymbery AJ (2008) The effect of salinity on the requirement for potassium by barramundi, Lates calcarifer, in saline groundwater. Aquaculture 278: 164-170.

87. Schwarzbaum PJ, Wieser W, Niederstatter H (1991) Contrasting effects of temperature acclimation on mechanisms of ionic regulation in a eurythermic and a stenothermic species of freshwater fish (Rutilus rutilus) and (Salvelinus alpinus). Comparative Biochemistry and Physiology 98: 483-489.

88. Tang CH, Leu MY, Shao K, Hwang LY, Chang WB (2014) Short-term effects of thermal stress on the responses of branchial protein quality control and osmoregulation in a reef-associated fish, Chromis viridis. Zoological Studies 53: 21.

89. Hochachka PW, Somero GN (2002) Biochemical adaptation: mechanism and process in physiological evolution 480. Oxford University Press, New York.

90. Schreck CB, Tort L (2016) The Concept of Stress in Fish. In Fish Physiology - Biology of In: CB Schreck, L Tort, AP Farrell, CJ Brauner (Eds.) Fish Physiology-Biology of stress in fish. 35 Academic Press Inc San Diego, United States Elsevier. pp. 1-34.

91. Martínez-Montaño E, Pontigo JP, Yáñez A, Ruiz-Jarabo I, Mancera JM, et al. (2015) Effects on the metabolism, growth, digestive capacity and osmoregulation of juvenile of Sub-Antarctic Notothenioid fish Eleginops maclovinus acclimated at different salinities. Fish Physiol Biochem 41: 1369-1381. [crossref]

92. Wang PJ, Lin $\mathrm{CH}$, Hwang HH, Lee TH (2008) Branchial FXYD protein expression in response to salinity change and its interaction with $\mathrm{Na}+\mathrm{K}+$-ATPase of the euryhaline teleost Tetraodon nigroviridis. Journal of Experimental Biology 211: 3750-3758. [crossref]

Kolbadinezhad SM, Hajimoradloo A, Ghorbani R, Joshaghani H, Wilson JM (2022) Effect of Short-term Elevation Temperature and Salinity Stress on Caspian Roach, Rutilus caspicus. Aquac Fish Stud Volume 4(1): 1-10. 